\title{
Türkçe Dersi ve Türk Dili ve Edebiyatı Dersi Öğretmen Adaylarının Sahip Olması Gereken Erdemler ve Yeterlilikler
}

\section{Hamza AYDOĞDU*}

\section{ÖZ}

Ĕ̆itim, bireysel ve toplumsal değişimin istendik şekilde olmasını să̆lamaktadır. Bireyin sosyal yaşamında sahip olduğu değerler önce ailede sonra da eğitim sürecinde şekillenmektedir. Öğrenenin eğitim sürecinde kendi kültürünü evrensel değerlerle yoğurarak yaşamına yansıtması erdemli bir yaşam içinde bulunmasını sağlayacaktır. Öğgretmenlerin kişisel yaşamları ile mesleki yaşamları arasında kuvvetli bir bağ vardır.

Değerlerini yeterlikleriyle birleştiren öğretmenler, toplumsal yaşamın temel kaideler üzerinde yükselmesine en büyük katkıı sağlayacak kişiler olacaktır. Milli benliğin oluşması, milli kültürün devamı, sosyal dayanışma için öğretmenlerin duygusal, teknolojik yeterliklerin yanı sıra kendi benliklerine duyacakları öz yeterlikleri de etkili olmaktadır. Değişen sosyal, ekonomik ve toplumsal koşullar toplumsal yapıyı etkileyerek, çok kültürlü bir toplumun ortaya çıkmasını sağlamıştır. Tüm bu değişimler eğitim sistemini de etkilemektedir. Ĕ̆itim sisteminin temel taş1, okullar ve öğretmenlerdir. Öğretmenlerin kendi alanlarıyla ilgili yeterlikler üstünde uzmanlaşması, mesleğin profesyonelleşmesini de sağlayacaktır. Özellikle Türkçe ve Edebiyat öğretmenleri sınıf içi akademik başarının artırılmasında, gelecek nesillerin kendi öz kültürleri ile yetiştirilmesinde ve hem milli hem evrensel eğitim hedeflerine ulaşılmasında önemli etkiler yaratmaktadır. Öğretmenlerin sahip olması gereken bilgi, beceri ve davranış özellikleri yeniden değerlendirilmelidir. Bu araştırma, Türkçe ve Edebiyat öğretmenlerinin sahip olması gereken yeterlikleri, alan yazın taraması ile ele alarak teorik bir çerçeve sunmak amacıyla hazırlanmıştır. Araştırmanın öğretmenle-

Dr. Aksaray Valisi, Aksaray/Türkiye

E-posta: hmzaydogdu@hotmail.com,ORCID:0000-0002-7363-7542,DOI:10.32704/erdem.755185 Makale Gönderim Tarihi: 10.04.2020 * Makale Kabul Tarihi: 21.06.2020 * (Araştırma Mk.) 
re, akademisyenlere ve uygulayıcılara farklı bir perspektif geliştirmesi beklenmektedir. Literatür taraması, öz yeterlik, duygusal zekâ yeterliği, çok kültürlüğü yönetme yeterliği, teknolojik yeterlik ve özel alan yeterliği başlıkları altında yapılan bu araştırmada, araştırmanın temel alanlarına ilişkin bilimsel araştırma sonuçlarına yer verilmiştir. Elde edilen bulgular üzerinden analize gidilerek değerlendirme ve sonuçlara ulaşılmıştır. Araştırma sonuçları göstermektedir ki öğretmen erdem ve yeterlilikleri için ilk sıralarda yer alan öz yeterlik, duygusal zekâ yeterliği, çok kültürlülüğü yönetme yeterliği, teknolojik yeterlik ve özel alan yeterliği gibi unsurlar öğretmenlik mesleğinin temel bileşenleri arasında yer almaktadır. Bu yeterlikler içinde alan yazında en çok çalışılan yeterlilikler öz yeterlik ve teknolojik yeterlik becerileri olarak görülmüştür. Duygusal zekâ yeterliğii, çok kültürlülüğü yönetme yeterliği ve özel alan yeterliği üzerine göreli olarak daha az çalı̧̧maya rastlanmıştır. Türkçe öğretimi ve Edebiyat öğretimi alanlarında, örnek bir rol model olarak öğretmen adaylarının Türk kültürünün en önemli değerleri olan duygudaşlık, hoşgörü içinde olma ve her bir bireyi bu hoşgörü içinde değerlendirme erdemine sahip olması önemli ve gereklidir. Araştırmanın bilimsel araştırma sonuçlarına dayanılarak ele alınan bu beş erdem ve yeterlilikler; eğitim hedeflerinin gerçekleştirilmesi, MEB' nın 2023 Vizyon Belgesinde yer alan tasarım beceri atölyelerinin amacına uygun tasarlanması ve kullanılması için oldukça önemli ve gereklidir.

Anahtar Kelimeler: Öz Yeterlik, Duygusal Zekâ Yeterliği, Çok Kültürlüğü Yönetme Yeterliği, Teknolojik Yeterlik, Özel Alan Yeterliği 


\title{
Turkish and Turkish Language and Literature Course Candidates Must Have Qualifications and Competencies
}

\begin{abstract}
Education ensures that individual and social change is desired. The values that the individual has in his social life are shaped first in the family and then in the education process. The learner will reflect his own culture with universal values in the education process and reflect his life in a virtuous life. There is a strong link between teachers' personal and professional lives. Teachers who combine their values with their competencies will be the ones who will make the biggest contribution to the rise of social life on the bases. In addition to emotional and technological competencies, teachers' self-efficacy will be effective for the formation of national self, continuation of national culture, and social solidarity. Changing social, economic and social conditions influenced the social structure, resulting in a multicultural society. All these changes also affect the education system. The cornerstone of the education system is schools and teachers. Specialization of teachers on competencies related to their own fields will also provide professionalization of the profession. Especially Turkish and Literature teachers have significant effects on increasing academic success in the classroom, raising the next generations with their own cultures and achieving both national and universal educational goals. The knowledge, skills and behavioral characteristics of teachers should be reevaluated. This research has been prepared in order to present a theoretical framework by addressing the competencies that Turkish and Literature teachers should have through literature review. Research; teachers, academics and practitioners are expected to develop a different perspective. In this research conducted under the headings of literature review, self-efficacy, emotional intelligence competence, multicultural management competence, technological competence and special field competence, scientific research results related to the main areas of the research were included. Based on the findings, analysis and results were obtained by analyzing. The results of the research show that the first place for teacher virtue and qualifications such as self-efficacy, emotional intelligence competence, competence to manage multiculturalism, technological competence and special field competence are among the basic components of the teaching profession. Among these qualifications, the most studied qualifications in the literature were seen as self-efficacy and technological competence skills. Relatively fewer studies were found on emotional intelligence competence, competence in managing
\end{abstract}


multiculturalism, and special field competence. As an exemplary role model in the fields of Turkish language teaching and literature teaching, it is important and necessary that teacher candidates have the virtue of being sympathetic, tolerant and evaluating each individual in this tolerance, which is the most important values of Turkish culture. These five virtues and qualifications, which are handled based on the scientific research results of the research; The realization of the training goals is very important and necessary for the design and use of the design skill workshops in the 2023 Vision Document of MEB.

Keywords: Self-Efficacy, Emotional Intelligence Competence, Multicultural Management Competence, Technological Competence, Special Field Competence. 


\section{Giriş}

ünümüzde okulun işlevlerinin değişmesi, öğretmenden beklentileri $\checkmark$ de değiştirmiştir. Geleneksel öğretmen anlayışında bilgiyi aktaran kişi iken, günümüzde öğretmen bilgiye ulaşmada farklı kaynakları işaret ederek, doğru bilginin elde edilmesi yönünde öğrencilerine öğrenmeyi öğreten kişi olmuştur. Aynı zamanda öğrenmeyi yaşam boyu sürdüren bir birey olmanın da rol modelidir. Tüm bunlar öğretmenin öncelikle kendi yaşamıyla ilgili öz yeterliğe sahip olmasını gerektirmektedir. Yeterlik, insanın, bilgi ve beceriye sahip olarak bir davranışı gerçekleştirmesidir (Başaran, 2000; Töremen ve Kolay, 2003). Öğretmenin öğrenme olanaklarını etkin bir şekilde kullanması, kendi öğretim alanına hâkim olması, öğrenmeyi kolaylaştırması gerekmektedir. Çağımızda öğretim ve yönetimin, ilke ve yöntemleri sürekli değiştiğinden, ögretmen yeterlikleri de sürekli değişmektedir (Bursalığlu, 2003; Güçlü, 2003; Gümüşeli, 2006). Bu nedenle 21.yy becerilerinin dolayısıyla, girişimcilik, çok kültürlülük, kapsayıcı olmak, etkili iletişim, yenilikçi ve yaratıcı düşünme, eleştirel ve çözüm odaklı düşünme becerileri öğretmenin yeterlik alanlarının da bu yöne doğru evrilmesine neden olmuştur. Öğretmenlik mesleği, alan bilgisi pedagojik ve teknolojik açıdan bireyin kendini sürekli geliştirmesi gereken bir meslektir (Bayrak, 1999). Eğitim bilimi araştırmaları, öğretmenlerin yeterliklerinin arttıkça daha nitelikli öğrencilerin yetiştirilebileceğini göstermektedir (Gözütok, 1995; Gürkan, 1993; Mentiş, 2004). Öğretmen yeterliliklerinin, eğitim hedeflerinin başarısına etkisi uluslararası düzeyde yapılan PISA, TIMMS gibi sınavlarda da görülmektedir.

\section{Problem Durumu}

\section{Amaç}

$\mathrm{Bu}$ araştırma, edebiyat öğretmenlerinin sahip olması gereken yeterlikleri alan yazın taraması ile ele alarak teorik bir çerçeve sunmak amacıyla hazırlanmıştır. Araştırmanın öğretmenler, akademisyenler ve uygulayıcılar açısında farklı bir perspektif geliştirmesi beklenmektedir. Bu araştırmada literatür taraması; öz yeterlik, duygusal zekâ yeterlikleri, çok kültürlüğü yönetme yeterliğii, teknolojik yeterlik ve özel alan yeterliği başlıkları altında yapılmıştır.

\section{Yöntem}

\section{Araştırmanın Modeli}

$\mathrm{Bu}$ araştırmada edebiyat öğretmenlerinin sahip olması gereken yeterlikleri, alanyazın taraması ile ele alınmı̧̧ır. Edebiyat öğretmenlerinin yeterlik- 
lerine ilişkin teorik çerçeve, bulgular ve araştırma sonuçlarına dayanarak çizilmektedir. Araştırmanın literatür taraması için belirlenen temel yeterlikler, araştırma sonuçlarından elde edilen sonuçlara, alan uzmanlarının görüşlerine ve Millî Eğitim Bakanlığı'nın 2023 Eğitim Vizyonuna göre belirlenmiştir.

\section{Bulgular}

\section{Erdem: Öz yeterlik}

Öz yeterlik, kişilerin bir iş ya da bir sorunla karşılaştıklarında gösterdikleri özgüvenli çabadır. Bu çabalar zaman zaman farklı iç ve dış koşullardan olumlu ya da olumsuz şekillerde etkilenebilir. Ancak bilgimize, becerimize ya da herhangi bir konuda kendimize güvenerek hareket etmemiz, öz yeterliğimizin bir göstergesi olarak kabul edilebilmektedir. Zimmerman’ da (1995) benzer bir tanım yaparak, öz yeterliğin "bireyin bir işi gerçekleştirebilme, başarabilme yeteneği konusundaki yargılarını” içerdiğini vurgulamaktadır. Öz yeterlik algısının güçlendirilmesinde dört ana kaynak vardır. Bunlar (1) tam ve doğru yaşantılar (emeğe dayalı başarı), (2) dolayl yaşantılar (sosyal ortamda emeğe dayalı bașarıların görülmesi), (3) Sosyal ikna (sözel olarak başarılı olunacağına ikna edilme) dir (Arslan, 2008).

Sosyal psikoloji alanında geliştirilmiş öz yeterlik kavramı birçok farklı disipline uyarlanmıştır (Kear, 2000; O’Leary, 1985; Lev, 1997; Schunk, 1985). Bandura'ya (1977) göre, bireylerin bir işi başarabileceğine ilişkin inanç, kariyer ilerlemesi ile paralel olan diğer iş alanlarındaki öz yeterlik inancının yükselmesini sağlamaktadır.

Öğrenci başarısı ile öğretmenlik öz yeterlik inançları arasındaki ilişkinin araştırıldığı bazı çalışmalarda öz yeterlik inancı yüksek öğretmenlerin, öğrencilerini daha başarılı kılacak yöntemleri kullanma isteklerinin daha fazla olduğu ve üst düzey performans sergiledikleri görülmüştür (Allinder, 1995, Ross, 1994).

Öğretmenlerin öz yeterliği ile ilgili bazı araştırmalarda Türkçe öğretmenliğinde okuyan adayların diğer bölümlere göre daha yüksek öz yeterlik algısına sahip oldukları (Karakuş, 2007; Çapri ve Çelikkaleli, 2008), bayan öğretmenlerin erkeklere göre daha yüksek yeterliğe sahip oldukları (Cheung, 2008), kıdemli öğretmenlerin diğerlerine göre daha yüksek özyeterlik algılarının olduğu (Karahan, 2006; Önen ve Öztuna, 2008) bu bağlantının kurulamadığı araştırmaların da var olduğu (Zengin Kapıc1, 2003; Ekici, 2006) görülmektedir. Öğretmen adaylarının katılımcı olduğu bazı çalışmalarda meslek 
için kendilerini oldukça yeterli gördükleri (Yangın, 2007; Altunbaş Gürol ve Karaaslan, 2010), sorgulama ve eleştirel düşünme becerilerinin öğretmen öz yeterlik düzeyine olumlu etki ettiğine de (Karademir, 2010) rastlanmıştır. Ortaöğretim öğretmenlerinin öz-yeterlik algılarının belirlenmesi için yapılan bazı araştırmalarda okul türüne (Üstüner, Demirtaş, Cömert, Özer 2009; Benzer, 2011) ve medeni durum, yaş, kıdem değişkenlerine göre (Benzer, 2011) öz yeterlik algısının farklılaştı̆̆ı görülmüştür.

\section{Erdem: Duygusal zekâ yeterliği}

Duygusal zekâ kavramı hem duygusal bilgiyi zihinsel olarak işleme süreci (Mayer, Salovey ve Caruso, 2004) hem de bir kişilik özelliği olarak (Petrides, Sangareasu, Furnham ve Fredrickson, 2006) kavramsallaştırılmıştır. Duygusal zekâ birçok özellik ve yeteneği kapsamaktadır (Mayer ve Salovey 1990, Mayer, Salovey ve Caruso 2004). Bireyin, başkalarının duygularını da değerlendirmeye ve ifade etmeye katkıda bulunmasını sağlayan duygusal zekâ yeterliği, başkalarının duygularını kontrol etmeye de yardımcı olmaktadır. Başarı sağlayıcı motivasyon gibi duyguları kullanmayı sağlayan çok sayıdaki yeteneği barındıran bu kavram, birbirine bağlı temel noktaların üzerinde gelişir. Bunlar;

- Duyguyu tam ve doğru olarak fark etme, algilayabilme ve kavrayabilme; yüz ifadesi, beden dili, ses tonu vb. sezme, yorumlama ve tanımlama yeteneği (Izard, 2001).

- Duyguların düşünceyi destekleme kapasitesi gerekli olduğunda duygulara ulaşabilme, onları üretebilme yeteneği, duyuşsal bilgi temeli (Izard, 2001).

- Duyguları ve onlardan gelen bilgiyi anlama yeteneği duyguları analiz edebilme, öngörme, sonuçlarını anlayabilmeyi (Frijda, 1988; Lane, Quinlan, Schwartz, Walker ve Zeitlin, 1990).

- Duygusal ve entelektüel gelişmeye itici güç olacak duyguları düzenleme yeteneği öz-bilgisi, sosyal farkındalık düzeyi, duyguların yönetilmesi (Weisinger, 1998; Kırt1l, 2009).

Duygusal zekâ yeterliği bir öğretmenin özellikle sınıf yönetimi anlamında en çok kullandığ 1 yeterliklerden biridir. Cooper ve Sawaf'a (2000) göre, öğretmenlerin koruyucu ve arkadaş olma, güvenirlik, dürüstlük, strateji oluşturma, yazma, konuşma, dinleme, müzakere etme, kararlılık, hayal gücü, cesaret, vic- 
dan, sezgi, alçak gönüllülük, gibi duygusal zekâ yeterliklerine sahip olması beklenmektedir. Öğretmenlik mesleğinde duygusal zekânın mükemmelliğin anahtarı olduğu da söylenilmektedir (Sarıkabak, 2018).

Edebiyat dersleri, ruhsal zekânın göstergeleri olan duygu, düşünce ve bütünün içinde olaylar arasındaki ilişkileri kavrama özelliğimizi geliştirmektedir. Edebiyat eğitimi, öğrencinin elde ettiği bilgileri, günlük yaşamında ve diğer bilgi platformlarıla sistemli bir biçimde birleştirerek kullanmasını sağlamakta ve düşünce sisteminin gelişmesine önemli ölçüde etki etmektedir. Öğretmenlerin, Türk Edebiyatı dersinde ruhsal zekâyı geliştirmeye yönelik yöntem ve teknikleri kullanması ile öğrenci kazanımlarının içselleştirilmesi de mümkündür.

Türkçe öğretmeni adayları üzerinde yapılan bir araştırmada; bayan adayların duygusal zekâ düzeylerinin (Yeşilyaprak, 2001; Köksal, 2003; Göçet, 2006; Korkman, Deniz, 2014), Eğitim Fakültesinde öğrenim görenlerin yükleme karmaşıklığı ve duygusal zekâlarının (Korkman, Deniz, 2014) ve empati kurma yeterliklerinin (Goleman, 2013) daha yüksek duygulara karş1 daha olumlu tutuma sahip (Ceyhan, 2000; Deng ve Zheng, 2004; Gürbüz, Yüksel 2008) olduklarını göstermiştir. Cinsiyet değişkeni açısından anlamlı farkların çıkmadığı araştırmalar da mevcuttur (Varışçığlu, 2014; Acar 2002; İşmen 2004; Girgin 2009). Öğretmen Lisesi mezunu öğretmen adaylarının duygusal zekâlarının diğer lise türlerinden mezun olan öğretmen adaylarından (Çeliköz, 2004) daha yüksek olduğu görülmüştür.

\section{Erdem: Çok kültürlülüğü yönetme yeterliği}

Çok kültürlük; ırk, etnik yapı, dil, cinsel yönelim, cinsiyet, yaş, engelli olma, sosyal sınıf, dinsel yönelim ve diğer kültürel boyutların bilinçli farkındalığıdır (APA, 2002). Çok kültürlülükte önemli olan, farklı kültürlerin varlıklarını sürdürmesine izin vermek olduğu kadar onların değerli olduklarını da kabul etmektir (Taylor, Appiah, Habermas, Rockefeller, Walzer, ve Wolf, 2010). Farklı kültürlerin birbirine bu bakış açısıyla yaklaşmasının sağlanması için öğretmenlerin çok kültürlü eğitimi benimsemeleri ve bu yöndeki yeterliklere sahip olmaları gerekmektedir. Bu bağlamdaki yeterlikler; insan haklarına sayg1 duyma, kültürel farklılıkları hoş karşılama, eğitimde kültürel çeşitliliği yansıtıcı firsat eşitliği sağlama ve eğitim ortamlarını düzenleme, farklı bakış açılarına ve fikir analizlerine profesyonelce yaklaşma gibi yeterliklerdir. Gay'a (2002) göre çok kültürlü yeterlikleri; kendi kültürel kimliği ve ön yargılarının farkında olma, kendi kültüründen farklı olan grupların dünya görüşlerini 
öğrenme eğiliminde olma ve kültüre duyarlı öğretim yöntemlerini geliştirme boyutlarını içeren yeteneklerdir. Bu da ancak eğitimle gerçekleşebilir. Gelişmiş ülkeler eğitim sistemlerinin geliştirilmesi ve sorunlara daha doğru çözümlerin bulunması için çok kültürlü eğitim çalışmalarına yer vermektedir (Cırık, 2008). Çok kültürlü eğitim anlayışı, toplumsal değişimlere hoşgörü gösterebilmeyi öğrenme sürecinde, sosyal güven, sosyal iletişim ve sosyal sorumluluk anlayışı üzerine kurulabilir (Eliott vd, 2000).

Çok kültürlü eğitimde öğretmen yeterlikleri ile ilgili araştırmalar çok kültürlü yeterliğe sahip öğretmenlerin kültürler arası anlayışı desteklediği, daha az duygusal ve davranışsal problemlerle karşılaştı̆̆1 ve öğrencilerinin akademik başarı düzeylerini arttırdığını göstermektedir (Kitsantas, 2011). Yılmaz (2020) tarafindan yapılan araştırmada öğretmenlerin; cinsel yönelimler, siyasi düşünceler gibi tercihlerde öğrencilere yönelik tutum ve davranışlar bakımından desteğe ihtiyaç duydukları ve sınıf yönetimi açısından bir sorun yaşamadıkları, öğretme yöntem ve tekniklerini öğrencilerin çok kültürlü özelliklerine göre değiştirdikleri, çok kültürlü eğitimin öğrencilerin hayatı, kültürleri ve farklı yaşam tarzlarını tanıma, sevgi-sayg1-hoşgörü geliştirme, kendi dünya görüşünü sorgulama, kendini sorgulama, ayrıştırmamayı öğrenme, birlikte yaşamayı öğrenme gibi katkılar sunduğunu ifade ettikleri görülmektedirler. Ezer, Millet ve Patkin'in (2006), İsrail'de bulunan iki üniversitenin eğitim fakültelerinde yaptıkları çalı̧̧mada, çok kültürlü eğitimin önemli olduğu bulunmuş olsa da çok kültürlü eğitimi hayata geçirme konusunda sıkıntılar yaşandığ1 görülmüştür. Taylor ve Quintana (2003), çok kültürlülüğe dayalı hazırlanmış bir eğitim programının neyin nasıl öğretileceğinin, öğretmenin kişisel özelikleri, farkındalığ1 ve bilincinin önemli olduğunu dile getirmektedirler. Öğretmenlerin çok kültürlü eğitime yönelik olumlu tutuma sahip oldukları (Doğanay, 2011) ve ırk din dil toplumsal sınıf ayrımı yapmadıkları (Yurtseven, 2003), farklı öğrencilerle çalışma deneyiminin önemli olduğunu düşündükleri (Başbay ve Kağnıcı, 2011), kıdemi daha düşük öğretmenlerin diğerlerine göre daha olumlu bir tutum sergiledikleri (Yazıcı, 2009) görülmektedir.

\section{Erdem: Teknolojik yeterlik}

21.yy'ın bireylerde aradığı temel beceriler arasında öğrenmeyi öğrenme, kendi öğrenmesini yönetme, bilgi okuryazarlı̆̆1 ve yaratıc1lık yeteneğinin somuta dönüştürülmesi gibi beceriler yer almaktadır. Farklı düşünerek bilgiyi analiz etme ve kendi anlayış süzgecinden geçirerek yenilik geliştirme bir sonraki adım olarak gelmektedir. Günümüz şartlarında bireyin sosyal ve ekonomik 
alanda başarı gösterebilmesi tam da bu yeterliğe bağlıdır. Öğretmenlerin çağın bu gereksinimlerine bağlı olarak yeterlilik geliştirmesi beklenen ve istenilen bir durumdur. Teknolojik yeterlilik; bilgisayar kullanabilmede, sosyal medyayı yönetebilmede, web araçlarına hâkim olmada yeterliği kapsamaktadır. Aynı zamanda internet kaynaklarını etkin kullanabilme, bilişim odaklı düşünebilmek de bu yeterlikler içinde yer almaktadır.

Çelik ve Bindak (2005), ilköğretim okullarında görev yapan öğretmenlerin bilgisayara yönelik tutumlarını inceledikleri araştırmalarında, bilgisayar öz yeterliği ve bilgisayar kullanma sıklığı ile bilgisayara yönelik olumlu tutum geliştirme arasında pozitif ve anlamlı ilişkiler saptamışlardır.

Millî Eğitim Bakanlığı, öğretmenlerin teknolojiyi kullanabilen ve rol model olan kişiler olmasını beklemektedir. 'Eğitimde Fatih Projesinin Öğretmenlerin Yeterlik Durumları Açısından İncelenmesi' isimli araştırmada öğretmenlerin bilgisayara/teknolojiye ilişkin öz yeterliliklerinin ve tutumlarının çeşitli nedenlerle yeterli düzeyde olmadığı sonucuna ulaşılmıştır (Kayaduman, Sırakaya, Seferoğlu, 2011). FATİH projesinin ve benzer diğer projelerin başarıya ulaşabilmesi için öğretmenlerin teknolojik yeterliklere sahip olması, bu yöndeki gelişimlerinin önünün açılması gerekmektedir.

Türkçe ve Türk Dili ve Edebiyatı dersi öğretmenlerinin bilgi okuryazarl1ğ1 açısından orta düzeyde öz yeterlik inancına sahip oldukları (Akkoyunlu, Kurbanoğlu, 2004), Türk Dili ve Edebiyatı öğretmen adaylarının ise derslerinde öğretim teknolojilerinden en üst düzeyde yararlanmak gerektiğini ifade edenlerin de orta düzeyde olduğu (Erdem, 2012) görülmektedir. Bu durum derslerine teknolojiyle nasıl bir katkı sağlayacakları konusunda kararsız olmaları şeklinde yorumlanmıştır.

\section{Erdem: Özel alan yeterliği}

MEB (2008) öğretmenlik mesleğine yönelik yeterlikleri, öncelikle öğretmenlik mesleği genel ve özel alan yeterlikleri olarak değerlendirmektedir. Özel alan yeterliğii, bilgi ve farkındalık, zenginleştirme, özgünleştirme ve işbirlikçi çalışma, beceri geliştirme, alanında mesleki gelişim sağlama, okul, aile ve toplumla iş birliği yapma, iletişim kurma, yaratıcı ve estetik olma, değerlendirme yapma gibi yeterliklerle tanımlamaktadır. Özel alan yeterlikleri bakanlık makamının 4 Haziran 2008 ve 25 Temmuz 2008 tarihli onaylarıyla yürürlüğe girmiştir. Bu yeterlik alanları, öğretmenlerin branşlarına göre değişmektedir. Okul öncesi öğretmenlerinin özel alan yeterliklerinin içinde gelişim alanlarını bilme, ailelerle iletişim, aile katılımı ve aile eğitimi etkinlikleri gibi yeterlikler 
yer almaktadır. Türkçe öğretmenlerin özel alan yeterliklerinin içinde de dil becerilerini geliştirme, dil gelişimini izleme, Türkçe öğretim sürecini planlama ve düzenleme gibi yeterlikler bulunmaktadır. Örneğin, sınıf öğretmenliği özel alan yeterlikleri 8 yeterlik alanı, 39 yeterlik ve bu yeterliklere ait 214 performans göstergesinden oluşmaktadır. Bunlar;

- Öğrenme Öğretme Ortamı ve Gelişim

- İzleme ve Değerlendirme

- Bireysel Sorumluluklar ve Sosyalleşme

- Bireysel ve Mesleki Gelişim-Toplum ile İlişkiler

- Dil Becerilerini Geliştirme

- Bilimsel ve Teknolojik Gelişim

- Beden Eğitimi ve Güvenlik

- Sanat ve Estetiktir.

Alan yeterlikleri belirlenirken performans göstergeleri A1, A2, A3 olarak düzeylerine göre belirlenmiştir (MEB 2008). Bu yeterlilik düzeyleri:

"A1 Düzeyi: Öğretmenin öğretim programına ilişkin uygulamalarındaki farkındalı̆̆ ile ögretmenlik mesleğine ilişkin sahip olduğu temel bilgi, beceri ve tutumları gösteren performans göstergelerini içerir.

A2 Düzeyi: Öğretmenin A1 düzeyindeki bilgi ve farkındalı̆̆ının yanı sıra, ögretim surecindeki uygulamalarında edindiği mesleki deneyimlerle programın gereğini yerine getirdiği, uygulamaların çeșitlendirdiği, ögrrenci ilgi ve ibtiyaçlarını dikkate aldiğı performans göstergelerini içerir.

A3 Düzeyi: Öğretmenin A2 düzeyinde geliștirdiği uygulamalarını, ögretimin farklı değiskenlerini de göz önünde bulundurarak özgün bir şekilde çeşitlendirmesini gerektiren performans göstergelerini içerir. Bu düzeydeki performans göstergelerine sabip olan ögretmen, özgün yorumuna dayalı yeni uygulamalarla alanına katkı sağlayabilir; meslektaşları, veliler, sivil toplum kuruluşları ve diğer kurumlarla sürekli iş birliği yapabilir” (MEB, 2008). 
MEB' nın (2017) Türk Dili ve Edebiyatı Öğretmeninin alan yeterlikleri aşağıdaki gibi ele alınmaktadır;

- Edebiyata ilişkin kavramları, akımları, kuramları ve metinleri inceleyebilme

- Türk edebiyatının dönemlerini ve metinlerini inceleyebilme

- Metinleri kavramlar, akımlar, sanatlar ve kuramlar çerçevesinde çözümleyebilme olarak belirlenmiştir.

MEB’ nın (2017) Türk Dili ve Edebiyatı Öğretmeninde alan eğitimi bilgisi kapsamındaki yeterlikleri;

- Öğretim sürecini amaca uygun planlayabilme

- Dil ve edebiyat öğretimine ilişkin çeşitli materyal ve kaynaklardan yararlanabilme

- Öğrenme ortamları düzenleyebilme

- Öğrencilerin dinleme becerilerini geliştirebilme

- Öğrencilerin okuma becerilerini geliştirebilme

- Öğrencilerin konuşma becerilerini geliştirebilme

- Öğrencilerin yazma becerilerini geliştirebilme

- Öğrencilerin eleştirel ve yaratıcı düşünme, karar verme ve problem çözme becerilerini geliştirebilme

- İletişim becerisini geliştirebilme

- Öğrencilerin sanat eserlerinden zevk almalarını sağlayabilme

- Öğretim sürecini izleyebilme ve değerlendirebilme olarak belirlenmiştir.

MEB’nın (2023) Türk Dili ve Edebiyatı Öğretmeninde tutum ve değerler kapsamındaki yeterlikler ise;

- Türkçenin doğru, güzel ve etkili kullanımında öncülük edebilme

- Okuma kültürü oluşturabilme ve geliştirebilme

- Dil ve edebiyat alanındaki gelişmeleri izleyebilme

- Okul ve kurumlar arasında iş birliği sağlayabilme

- Ulusal ve evrensel değerlerin korunmasına ve estetik anlayışın geliştirilmesine duyarlı olabilme Atatürkçü düşünce çerçevesinde dil bilincini geliştirebilme olarak belirlenmiştir. 
Öğretmen Yetiştirme ve Geliştirme Genel Müdürlüğü tarafindan alan yeterliğine ilişkin 99 performans göstergesi, alan eğitimi bilgisine ilişkin 62 performans göstergesi, tutum ve değerlere ilişkin ise 31 performans göstergesi olmak üzere 161 performans göstergesi belirlenmiştir.

Alan yeterliği performans göstergelerine bakıldığında öğretmenlerin, öğrencilerin bilişsel becerilerini geliştirmeleri için gerekli yeterlik alanlarında iyi olmaları gerektiğinin altı çizilmektedir. Özellikle bilişsel becerilerinin geliştirilmesi için soru sorma ve cevap üretme becerilerinin geliştirilmesi, eleştirel ve analitik düşüncenin kazandırılması önemli görülmektedir. Karakuş'a (2002) göre bilişsel yeterlik sorunun cevabının doğrudan değil metne sindirilerek verilmesi gerekmektedir. Sınıf içinde araştırma ve öğrenme atmosferinin oluşturulması için farklı türde sorular üretilmeli ve sorulmalıdır (Sanders, 1966). Araştırmalardan bazıları, öğretmen adaylarının Bloom taksonomisine göre \% 13 analiz, \% 6 sentez, \% 11 değerlendirme düzeyinde soru sorabildiğini (Aydemir, Çifti 2008), okuma stratejilerini kullanma düzeylerinin beklenenden düşük olduğu sonucunu (Topuzkanamış,2009, Erdem, 2012), ilköğretim ikinci kademe Türkçe derslerinde sınav sorularının yarıdan fazlasının bilgi ve kavrama düzeyinde olduğunu (Güfta, Zorbaz, 2008), beş ortaöğretim okulunun Türkçe derslerinde sorulan soruların \% 31,3'ünün analiz, \% 7'sinin sentez ve \% 1,3'ünün de değerlendirme basamağında yer aldığını, lise düzeyi edebiyat derslerinde öğretmenlerin daha çok kapalı uçlu, çoktan seçmeli soruları tercih etmelerine rağmen dil ve anlatım dersinde daha çok açık uçlu ve analiz, sentez ve değerlendirmeye yönelik sorular sorduklarını (Türkyılmaz, 2008) göstermiştir. 


\section{DEĞERLENDİRME, SONUÇ VE ÖNERİLER}

Günümüz şartlarında Türkçe ve Türk Dili Edebiyatı öğretmenlerinin sahip olması gereken erdemler; bilgi, beceri ve davranı̧̧ özelliklerinin bir göstergesi olarak öğretmen yeterliklerini incelediğimiz bu çalışmada, alan yazın taramas1 yapılarak, teorik bir çerçeve sunulmuştur. Bu çerçevede ele alınan erdemler; öz yeterlik, duygusal zekâ yeterliği, çok kültürlülüğü yönetme yeterliği, teknolojik yeterlik ve özel alan yeterliği, 21.yy becerileri kapsamında değerlendirilmiştir. Araştırmanın bilimsel araştırma sonuçlarına dayanılarak ele alınan bu beş erdem ve yeterlilikler; eğitim hedeflerinin gerçekleştirilmesi, MEB' nın 2023 Vizyon Belgesinde yer alan tasarım beceri atölyelerinin amacına uygun tasarlanması ve kullanılması için oldukça önemli ve gereklidir. Bu yeterlikler içinde alan yazında en çok çalış1lan yeterlilikler öz yeterlik ve teknolojik yeterlik becerileri olarak görülmüştür. Duygusal zekâ yeterliği, çok kültürlülüğü yönetme yeterliği ve özel alan yeterliği üzerine göreli olarak daha az çalışmaya rastlanmıştır. Araştırma sonuçları göstermektedir ki öğretmen erdem ve yeterlilikleri için ilk sıralarda yer alan öz yeterlik, duygusal zekâ yeterliği, çok kültürlülüğ̈̈ yönetme yeterliği, teknolojik yeterlik ve özel alan yeterliği gibi unsurlar öğretmenlik mesleğinin temel bileşenleri arasında yer almaktadır. Türkçe öğretimi ve Edebiyat öğretimi alanlarında, örnek bir rol model olarak öğretmen adaylarının Türk kültürünün en önemli değerleri olan duygudaşlık, hoşgörü içinde olma ve her bir bireyi bu hoşgörü içinde değerlendirme erdemine sahip olması önemli ve gereklidir. Buna ek olarak, duygusal zekâ yeterliği ve çok kültürlülüğü yönetme yeterliği, MEB’ nın (2023) Türk Dili ve Edebiyatı Öğretmeninde bulunması gereken tutum ve değerler arasında saydığ1; ulusal ve evrensel değerlerin korunmasına yönelik çalışmaların gerçekleştirilmesini de destekleyecektir. Özellikle özel alan bilgisi yeterliği farklı branşlardaki öğretmenler açısından araştırılabilir. Ayrıca gerek Türkçe öğretimi gerekse Türk Dili ve Edebiyatı öğretimi alan yeterliliklerini belirleyen resmi kuruluşlar açısından bakıldığında, alan yeterliklerinin 21. yy gereklilikleri ve temel becerileri açısından yeniden ele alınması önerilebilir. Genel anlamda akademisyenler açısından 21.yy becerileri temelinde öğretmen yeterlikleri çalı̧̧ılabilir. Uluslararası karşılaştırmalı çalışmalar yapılarak evrensel ölçüde öğretmen yeterlikleri ortaya konabilir. 


\section{KAYNAKLAR}

Acar, F. (2002). Duygusal Zekâ ve Liderlik, Sosyal Bilimler Enstitüsü Dergisi, C.12 53-68

Arslan, A. (2008), Öğretmen adaylarının bilgisayar destekli eğitim yapmaya yönelik tutumları ile öz yeterlik algıları arasındaki ilişki, Elektronik Sosyal Bilimler Dergisi, C.7, 24 www.esosder.org, 10.01.2020

Akkoyunlu, B. Kurbanoğlu, S. (2004). Öğretmenlerin bilgi okuryazarllğ̣1 öz yeterlik inancı üzerine bir çalışma, Hacettepe Üniversitesi Ĕ̈itim Fakültesi Dergisi S: 27, 11-20.

Allinder. R. M. (1995). An examination of the relatianship between teacher efficacy and curriculum based measurement and student achievement. Remedial \& Special Education, 27, 141-152.

Aydemir, Y. Çifti Ö. (2008), Edebiyat öğretmeni adaylarının soru sorma becerileri üzerine bir araştırma, Yüzüncü Yıl Üniversitesi, Ĕ̈itim Fakültesi Dergisi. Haziran 2008. C.V, S:II, 103-115 http://efdergi.yyu.edu.tr, 02 Şubat 2020

Bandura, A. (1977). Self-efficacy: Toward a unifying theory of behaviour change. Psychological Review, 84,191-215.

Barriers to Learning. Rewiev of Business. Fall/Winter, 21 (3-4): 17-25.

Başaran, İ. E. (2000). Örgütsel davranış. Ankara: Gül Yayınevi.

Bayrak, C. (1999). Modern eğitimde öğretmen profili. Anadolu Üniversitesi Ë̆itim Fakültesi Dergisi, 9, 9-16.

Benzer, F. (2011). İlköğretim ve ortaöğretim kurumlarında görev yapan öğretmenlerin öz yeterlik algılarının analizi, Selçuk Üniversitesi Dijital Arşiv Sistemi, http://hdl.handle.net/123456789/2257, 15 Şubat 2020.

Cheung, Y. H. (2008). Teacher efficacy: a comparative study of Hong Kong and Shanghai primary in-service teachers. Australian Educational Researcher, 35(4), 103-123.

Cırık, İ. (2008). Çok kültürlü eğitim ve yansımaları. Hacettepe Üniversitesi Ë̆itim Fakültesi Dergisi, 34, 27- 40.

Cooper, R. K ve Sawaf, A. (1997). Liderlikte Duygusal Zekâ: Yönetimde ve Organizasyonda Duygusal Zekâ (EQ). Çev.: Z. B. Ayman ve B. Sancar, İstanbul: Sistem Yayincilik, 218. 
Ceyhan, A. A. (2000). Üniversite öğrencilerinin duygu ifade eden sözcük ve deyimlere yükledikleri duygu yoğunluklarının incelenmesi. Türk Psikolojik Danışma ve Rebberlik Dergisi, 2(13): 33-44.

Çelik H, C., Bindak, R. (2005). İlköğretim Okullarında Görev Yapan Öğretmenlerin Bilgisayara Yönelik Tutumlarının Çeşitli Değişkenlere Göre İncelenmesi. İnönü Üniversitesi Eğitim Fakültesi Dergisi, Cilt:6, Sayı:10.

Çeliköz, N. (2004). Anadolu öğretmen lisesi öğrencilerinin öğretmenlik mesleğine yönelik tutumlarını etkileyen etmenler. Milli Ĕgitim Dergisi, 32, $136-145$.

Çapri, B. ve Çelikkaleli, Ö. (2008). Öğretmen adaylarının öğretmenliğe ilişkin tutum ve mesleki yeterlilik inançlarının cinsiyet, program ve fakültelerine göre incelenmesi. İnönü Üniversitesi Eğitim Fakültesi Dergisi. 9 (15), 33-53.

Deng L.F., \& Zheng, R.C. (2004). Affect variables and mental health in college students. Chinese Mental Health of Journal, 18: 58-60.

Doğanay, A. (2011). Hizmet öncesi öğretmen eğitiminin öğretmen adaylar1nın felsefi bakış açılarına etkisi. Ĕğitim ve Bilim, 36(161), 332-348

Ekici, G. (2006). Meslek lisesi öğretmenlerinin öğretmen özyeterlik inançları üzerine bir araştırma, Eurasian Journal of Educational Research (EJER), I. 24, 87-96.

Eliot, D., D. Smith ve M. McGuinness (2000). Exploring the Failure to Learn: Crises and the

Erdem, C. (2012). Türk dili ve edebiyatı öğretmen adaylarının okuma stratejilerini kullanma düzeyleri, Uluslararası Türkçe Edebiyat Kültür Eğitim Dergisi Say1: $1 / 4,162-186$.

Erdem, C. (2012). Türk dili ve edebiyatı ögrretmeni adaylarının öğretmenlik mesleğine yönelik yeterlilik algıları ve tutumları üzerine bir araştırma, International Periodical For the Languages, Literature and History of Turkish or Turkic, Volume 7/4,

Ezera, H., Millet, S. \& Patkins, D. (2006). Multicultural perspectives in the curricula of two colleges of education in Israel: The curriculum is a cruel mirror of our society. Teachers and teaching: Theory and practice, 12, 391-406.

Frijda, N. H. (1988). The laws of emotion. American Psychologist, 43(5), 349358. 
Gay, G. (2002). Preparing for culturally responsive teaching. Journal of Teacher Education, 53, 106-116. Retrieved from http://www.sagepub.com/eis/Gay.pdf Girgin, G. (2009). Üniversite Öğrencilerinde Duygusal Zekânın Bazı Değişkenler Açısından İncelenmesi. [The Investiganion of Emotional Intelligence in Universty Stdudents to Some Variables]. KKTC Milli Eğitim Dergisi TRNC Journal of National Education, 3, 1-12

Goleman, D. (2013). Duygusal Zekâ. (Çev. B. Seçkin Yücel), İstanbul: Varlık /Bilim.

Göçet, E. (2006). Üniversite öğrencilerinin duygusal zekâ düzeyleri ile stresle başa çıkma tutumları arasındaki ilişki. Yayımlanmamış Yüksek Lisans Tezi, Sakarya Üniversitesi, Sosyal Bilimler Enstitüsü

Gürbüz, S. Ve Yüksel, M. (2008). Çalışma ortamında duygusal zekâ: iş performansı, iş tatmini, örgütsel vatandaşlık davranışı ve bazı demografik özelliklerle ilişkisi. Doğuş Üniversitesi Dergisi, 9 (2), 174-190

Gürkan, T. (2001). Bireyin çok yönlü gelişimi. Bilim ve Aklın Aydınlı̆̆ında Ĕ̈itim Dergisi. Sayı 22.

Gürol, A., Altunbaş, S., ve Karaaslan, N. (2010). Öğretmen adaylarının öz yeterlik inançları ve epistemolojik inançları üzerine bir çalışma. e-Journal of New World Sciences Academy, 5 (3), 1395-1404.

Gözütok, F. D. (1995). Öğretmenlerin Demokratik Tutumları, Ankara: Ekin Yayıncilik.

Izard, C. E. (1993). Four systems for emotion activation: Cognitive and noncognitive processes. Psychological Review, 100(1), 68-90.

İşmen, E. (2004). Duygusal zekâ ve aile işlevleri arasındaki ilişki. Balıkesir Üniversitesi Sosyal Bilimler Dergisi, 7(11), 55- 75.

Karakuş, İ. (2002). Türkşe Türk Dili ve Edebiyatı Öğretimi. Ankara: Anıttepe Yayınc1lik.

Karakuş, A. (2008). Sağlık meslek lisesi meslek dersi öğretmenlerinin iş doyumlarına ilişkin görüşleri (Ankara ili örneği). Yayınlanmamı̧̧ Yüksek Lisans Tezi. Muğla Üniversitesi Sosyal Bilimler Enstitüsü, Muğla.

Karahan, Ç. (2006). İlköğretim ikinci kademe öğretmenlerinin öz algılamaları ve mesleki doyumlarının incelenmesi. Yayımlanmamı̧̧ Yüksek Lisans Tezi. Ege Üniversitesi Sosyal Bilimleri Enstitüsü. 
Kurt1l, S. (2009). İlköğretim ikinci kademe ögrrencilerinin duygusal zekâ düzeyleri ile yaşam doyumu düzeylerinin incelenmesi. Yayınlanmamış Yüksek Lisans Tezi. Dokuz Eylül Üniversitesi, Eğitim Bilimleri Enstitüsü

Kitsantas, A. (2011). Teacher efficacy scale for classroom diversity (Tescd): A Validation Study. Retrieved from http://www.ugr.es/ recfpro/rev161ART3en.pdf

Korkman, H., Deniz. M.E. (2014). Üniversite öğrencilerinin bazı demografik değişkenlerinin yükleme karmaşıklığı, duygusal zekâ ve akıcı zekâ çerçevesinde incelenmesi, Anadolu Ĕ̈itim Liderliği ve Öğretim Dergisi, 2 (2), 14-28

Köksal, A. (2003). Ergenlerde duygusal zekâ ve karar verme becerileri arasındaki ilişki. Yayımlanmamış Yüksek Lisans Tezi, İstanbul Üniversitesi, Sosyal Bilimler Enstitüsü, İstanbul.

Lane, R. D., Quinlan, D. M., Schwartz, G. E., Walker, P. A. ve Zeitlin, S. B. (1990). The Levels of Emotional Awareness Scale: A cognitive-developmental measure of emotion. Journal of Personality Assessment, 55(1-2), 124-134.

Mentiş Taş, A. (2004). Sosyal bilgiler öğretmenliği eğitimi program standartlarının belirlenmesi. Ĕ̈itim Bilimleri Fakültesi Dergisi. Cilt: 37, sayı:1, 28-51.

Mayer,J. D., Salovey, P. ve Caruso, D. R. (2004). Emotional intelligence: Theory, findings, and implications. Psychological Inquiry, 15(3), 197-215.

Milli Eğitim Bakanlığ1 (2008). Öğretmen yeterlikleri kitabı. Ankara: Devlet Kitapları Müdürlüğü.

Milli Eğitim Bakanlığ1 (2017). Türk Dili Edebiyatı Öğretmenliği Alan Yeterlikleri Ankara: Öğretmen Yetiştirme Genel Müdürlüğü, http://oygm.meb. gov.tr, 02 Mart 2020

Okutan, M. (1988). Orta Dereceli Okul Müdürlerinin İnsan İlişkileri Yeterlikleri (Trabzon İli Örneği). Yayımlanmamış yüksek lisans tezi. Hacettepe Üniversitesi Sosyal Bilimler Enstitüsü. Ankara.

Öksüz, C. (1997). İlköğretim Okulları Müdürlerinin Öğretmenlerle İletişim Sürecindeki Yeterlikleri. Yayımlanmamış yüksek lisans tezi. Pamukkale Üniversitesi Sosyal Bilimler Enstitüsü. Denizli

Önen, F. ve Öztuna, A. (2005). Fen bilgisi ve matematik öğretmenlerinin öz yeterlilik duygusunun belirlenmesi. http://www.yeditepe.edu.tr, 02 Şubat 2020. 
Petrides, K. V., Sangareasu, Y., Furnham, A. ve Fredrickson, N. (2006). Trait emotional intelligence and children's peer relations at school. Social Development, 15(3), 537-547.

Ross, J. A. (1994). The impact of an inservice to promote cooperative learning on the stability of teacher efficacy. Teaching E Teacher Education, 10, 381-394. Sanders, N.M., (1966). Classroom Questions: What Kinds?, New York: Harper and Row

Sarıkabak, M. (2018). Spor bilimleri fakültesi öğrencilerinin sosyal fizik kayg1 durumları ve duygusal zekâ düzeylerinin incelenmesi. sportif bakıs $₫$ : Spor ve Ë̆itim Bilimleri Dergisi, 5(S.11), 74-85.

Topluer, A. (2008). İlköğretim Okulu Yöneticilerinin İletişim Yeterlikleri ile Örgütsel Çatışma Düzeyi Arasındaki İlişki (Malatya İli Örneği). Yayımlanmamış yüksek lisans tezi. İnönü Üniversitesi Sosyal Bilimler Enstitüsü. Malatya.

Taylor, G. N., \& Quintana, S. M. (2003). Teacher's multicultural competencies (K-12). In D. B. Pope Davis, H. L. K. Coleman, W. M. Liu \& R. L. Toporek (Eds)., Handbook of multicultural competencies in counseling and psychology. California: Sage Publications.

Türkyılmaz, M. (2008). Dil ve anlatım dersinde bir ölçme aracı olarak yazılı sınavların kullanımı konusunda öğretmen görüşleri, Ahi Evran Üniversitesi Kırşehir Ë̆itim Fakültesi Dergisi, Cilt 9, Sayı 3, 1-14

Topuzkanamış, E. (2009). Öğretmen Adaylarının Okuduğunu Anlama ve Okuma Stratejilerini Kullanma Düzeyleri. Yayımlanmamı̧̧ Yüksek Lisans Tezi, Balıkesir: Balıkesir Üniversitesi Sosyal Bilimler Enstitüsü.

Töremen, F. ve Kolay, Y. (2003). İlköğretim okulu yöneticilerinin sahip olmas1 gereken yeterlikler. Milli Ĕgitim Dergisi, Sayı:160. 10 0cak 2020.

Üstüner, M. Demirtaş, H. Cömert, M. Özer N. (2009). Ortaöğretim öğretmenlerinin öz-yeterlik algıları, Mehmet Akif Ersoy Üniversitesi Ĕgitim Fakültesi Dergisi, Y11 9, Say1 17, Haziran 2009, 1-16

Varışçı̆̆lu, B. ( 2014). Dil kullanımının bir yansıması olan duyguları dile getirme becerisiyle duygusal zekâ arasındaki ilişki: türkçe öğretmeni adayları örneklemi, International PeriodicalfortheLanguages, Literatureand History of Turkish or Turkic, Volume 12/14. 
Wessinger, H. (1998). Emotional intelligence at work. San Francisco: JosseyBass Inc.

Yazıcı, S., Başol, G., ve Toprak, G. (2009). Öğretmenlerin çokkültürlü eğitim tutumları: bir güvenirlik ve geçerlik çalışması. Hacettepe Üniversitesi Ĕgitim Fakültesi Dergisi, 37, 229-242.

Yurtseven, R. (2003). Ortaöğretim kurumlarında çalışan öğretmenlerin demokratik tutumları. Yayımlanmamış Yüksek Lisans Tezi. Çukurova Üniversitesi, Sosyal Bilimler Enstitüsü

Yeşilyaprak, B. (2001). Duygusal zekâ ve eğitim açısından doğurguları. Kuram ve Uygulamada Eğitim Bilimler Dergisi, 25: 139-146.

Yılmaz G. F. (2020), Çok kültürlü eğitime ilişkin öğretmen algıları, Milli Ĕ̈itim Dergisi, Cilt 49, Sayı 226, 291-321.

Zengin Kapıc1, U. (2003). İlköğretim öğretmenlerinin öz-yeterlilik algıları ve sınıf-içi iletişim örüntüleri. Yayınlanmamış Yüksek Lisans Tezi. D.E.Ü. Ĕ̆itim Bilimleri Enstitüsü.

Zimmerman, B. J. (1995). Self-efficacy and educational development. In A. Bandura (Ed.). Self-efficacy in changing socities. New York: Cambridge University Press (pp. 202-231). 